January 2015

\title{
Productive Confusion: Advancing Intercultural Perspectives Through A Multicultural Professional Development Program For Educational Leaders
}

\author{
Jack Frawley \\ Australian Catholic University, Jack.Frawley@acu.edu.au \\ Kim Anh Dang \\ Vietnam National University - Hanoi \\ Daravone Kittiphanh \\ Ministry of Education, Laos PDR
}

Follow this and additional works at: https://digitalscholarship.unlv.edu/jpme

\author{
Repository Citation \\ Frawley, Jack; Dang, Kim Anh; and Kittiphanh, Daravone (2015) "Productive Confusion: Advancing \\ Intercultural Perspectives Through A Multicultural Professional Development Program For Educational \\ Leaders," Journal of Praxis in Multicultural Education: Vol. 9: No. 1, Article 5. \\ DOI: 10.9741/2161-2978.1077 \\ Available at: https://digitalscholarship.unlv.edu/jpme/vol9/iss1/5
}

This Article is protected by copyright and/or related rights. It has been brought to you by Digital Scholarship@UNLV with permission from the rights-holder(s). You are free to use this Article in any way that is permitted by the copyright and related rights legislation that applies to your use. For other uses you need to obtain permission from the rights-holder(s) directly, unless additional rights are indicated by a Creative Commons license in the record and/ or on the work itself.

This Article has been accepted for inclusion in Journal of Praxis in Multicultural Education by an authorized administrator of Digital Scholarship@UNLV. For more information, please contact digitalscholarship@unlv.edu. 


\section{Introduction and purpose}

The Centre for Creative \& Authentic Leadership (CCAL) at Australian Catholic University ${ }^{1}$ hosted a four AusAID ${ }^{2}$ funded Australian Award Fellowship (AAF)

programs during the period 2007 to 2013 . These programs progressively developed views and perspectives on interculturalism and intercultural leadership, by using the program's intercultural 'space' for teaching and learning. In this space, educational leaders learned from each other and contributed to an understanding of interculturalism. The focus on intercultural leadership was to address an imbalance where leadership remains too narrowly and dominated by Western-derived theories and practices (Walker \& Dimmock, 2002).

The AusAID stated goal of the AAF Program is to develop appropriately trained current and aspiring leaders who, in the short-to-medium term will be in a position to advance key regional policy issues. During the period 2007 to 2013, CCAL hosted four programs and 46 AAF Fellows primarily from South East Asia and the South Pacific. As a cohort, the AAF Fellows reflect a range of experiences, with most working in the field of education with a particular focus on marginalized sectors of their communities. For example, one female Indian AAF Fellow worked with Adivasis ${ }^{3}$ on a range of programs with a strong focus on environmental issues. Another, a male AAF Fellow from Cambodia, worked with the disabled in providing a range of services and advice on government policy. CCAL, as the Host Organisation, brought considerable scholarly expertise and reputation to the program, as well as an extensive background, track record and international experience in leadership development.

The program's teaching and learning approach developed overtime and was central to the AAF program. An Intercultural Leadership Module (ILM) was developed, designed and co-taught by AAF alumni and an Australian academic with intercultural and educational leadership theories as its foundation. The ILM had a number of aims

\footnotetext{
${ }^{1}$ Australian Catholic University is a public university funded by the Australian Government. CCAL was dissolved at the end of 2013 as a consequence of an ACU restructure.

2 AusAID (the Australian Agency for International Development) was the Australian Government agency responsible for managing Australia's overseas aid program. This responsibility now rests with the Department of Foreign Affairs and Trade (DFAT).

${ }^{3}$ Adivasis is the collective name used for the many indigenous peoples of India.
} 
including discussing and assessing the relevance of West-inspired theories on leadership for different cultural contexts; considering if there are differences within Fellows' countries in the ways in which leadership is defined and practised and, if so, identifying the differences; identifying existing theories on leadership and learning which have a non-West origin; discussing and defining interculturalism; and, identifying and developing appropriate capabilities for leadership in intercultural contexts.

This paper outlines the context of the AAF programs and presents and overview of the literature on educational leadership theories and practice from Western, Aboriginal and intercultural perspectives. Against this backdrop, the paper presents an analysis of emerging views and perspectives around intercultural leadership and the implications that these views have for further research. What occurred in the intercultural space of these programs was a melding of ideas and perspectives informed by the experiences of primarily South East Asian and South Pacific educational leaders and Australian academics steeped in the traditions, theories and practice of educational leadership. This intercultural space was viewed as an evolving one.

\section{Leadership, Aboriginal leadership and interculturalism}

Leadership is an alphabet soup: for most letters of the alphabet there is a corresponding leadership theory and/or leadership practice. Nevertheless, a number of categories assist in attempts to consume the soup. The trait category holds the view that leaders are born with or have charisma or specific traits, abilities, and skills (Stogdill, 1974). The behavioural view of leadership is that leadership capability can be learned, rather than being inherent (Merton, 1957). The situational category sees leadership as a matter of situational demands and the emergence of a leader as a result of time, place, and circumstance (Yukl, 1989). The process view of leadership is that it is a process of dynamic interaction among people, and is essentially dissipative (Burns, 1978; Bass, 1990). The values category believes that leadership has a moral dimension with a focus on, and a commitment to ethics, purpose, values and beliefs (Starrat, 2004; Duignan, 2006). Within this latter category authentic leadership is "knowledge based, values informed, and skillfully executed" and requires "professionally effective, ethically sound, and consciously reflective practices in educational administration" (Begley 2001, p 353). 
Authentic leadership "acknowledges and accommodates in an integrative way the legitimate needs of individuals, groups, organisations, communities and cultures" (Begley 2001, p.354). Although there appears to be 'no unitary concept of transformational leadership", there are a number of accepted generalisations and key concepts including the role of leadership in fostering "capacity development and higher levels of commitment" to the project's goals" (Leithwood \& Jantzi, 1999). Though Western leadership theories may reflect some relevant leadership styles and practices, arguably, they are problematic in the sense that they have not, in the main, widened the debate to include views from other cultures.

In writing about Australian Aboriginal leadership in general, Pearson (2000, p. 49), states that the major challenge facing Aboriginal communities is that current models of leadership have "arisen from the colonial experience and the experience of institutional life in the reserves". Pearson (2000, p. 37) argues that any successful new approach to leadership must incorporate a "shoulder to shoulder" encouragement, a sharing of, and devolution of, power that "hands on" power to members of the community. Furthermore, Pearson (2000) advocates a system of governance that incorporates key values such as cooperation, unity, respecting rights, sharing power, taking responsibility, encouraging others and supporting each other.

Patrick Dodson, former Chairperson of the Council for Aboriginal Reconciliation, in the Williamson Community Leadership Program Lecture (1998) emphasized the importance of leadership when he said:

For Aboriginal leaders, the social and moral obligation that comes with community leadership is life-long. Those who lead, who have authority, must care for and look after those who come behind. Leadership is an elusive concept, hard to describe and impossible to prescribe. It is more evident in its absence, so that when leadership is needed, its lack is sorely felt.

In recent years in Australia there has been an increased focus on Aboriginal educational leadership through a range of initiatives and strategies, for example the Stronger Smarter Institute programs, and Dare to Lead initiatives. The Stronger Smarter Institute at Queensland University of Technology hosts a leadership program which recognizes that principals, teachers, teachers' aides, parents and community elders are all leaders with a significant role to play in education for Indigenous students. Dare to Lead 
is a project managed by Principals Australia and is funded by the Australian Government Department of Education, Employment and Workplace Relations. An underpinning belief of the Dare to Lead project is that educational can make the most difference to the schooling outcomes of Aboriginal and Torres Strait Islander students.

In the last few years, two research projects have investigated educational leadership in remote Aboriginal communities. Kamara (2009) investigated and recorded the stories of five female Aboriginal school principals in the Top End of the Northern Territory on their leadership approaches in negotiating school community partnerships in their respective communities. The study revealed that the Indigenous female principals experienced enormous challenges and constraints in their efforts to demonstrate good educational leadership and work in partnership with their communities. The research concluded that community school leadership should be flexible and context bound, as rigid bureaucratic structures are inappropriate for Aboriginal community settings.

The Linking Worlds project (Frawley, Fasoli, d'Arbon \& Ober, 2010) investigated educational leadership in remote Aboriginal communities and aimed to frame the unique 'worlds' within which Aboriginal educational leaders operate, and to determine the skills, knowledge and attributes required to be an effective leader. The research confirmed that the role of an Aboriginal educational leader is multi-faceted requiring multi-dimensional responsibilities. The research also suggested that education in remote Aboriginal communities should be viewed as an intercultural system that functions well when there is respect and appreciation for different cultures and when they are allowed to flourish with creativity and dignity. In these settings it is important to have "a balance between balanda (non-Aboriginal) and bininj (Aboriginal) knowledge" (Bulliwana, Frawley \& Garnarradj, 2001). This idea of balance in central to Indigenous educational leadership and has parallels with the concept of interculturalism.

Interculturalism, as a concept, is widely defined (Coll, 2004; Abdallah-Pretceille, 2006; Bouchard \& Taylor, 2008; Meer \& Modood, 2012); nevertheless, it does provide some interesting points of departure for programs such as AAF. The interest for the AAF program lies with the similarities of interculturalism with an Australian Aboriginal concept of 'both ways'. Within the 'both ways' concept there is a focus on the intersection and linking of cultural 'worlds' and the 'space' in which the overlap occurs. 
Within the concept of 'both ways', Wunungmurra $(1989,12)$ emphasizes maintaining identity and finding common ground where through "an exchange of knowledge both sides learn from each other instead of knowledge coming only from the balanda (nonAboriginal) side."

Chan et al. (2008, p. 72) discuss the overlapping space when two cultures work together as a combined space "where hybrid forms of knowledge and skills are enriched". This combined space "is an intercultural space where leadership is informed by both the specific culture in which it is located, and western theories and leadership practice from which it is influenced." Chan et al. (2008, p. 72) conclude, "This calls for leaders to develop mutuality and to be polychronic. Leaders will be required to juggle many of the demands that occur in this intercultural space". An Aboriginal educator from northeast Arnhem Land, Yalmay Yunupingu, states "I want to bring Western and Yolngu culture to a balance, to balance it, not one up here and one down here. Everything should be balanced, We come from a balanced world - yirritja and dhuwa" (Alterator, 2010). In this context, 'balance' remains central to an understanding of interculturalism.

\section{Methods and procedures}

The basic ideas of how qualitative research is conducted is evident in this research: it is based on the assumption that there are multiple realities; that the events under study are viewed holistically; and, it is the perceptions of those being studied that are important (Wiersma, 1995). The AAF research is particularistic in that it focused on a specific situation, resulting in a rich and thick description around the Fellows emerging views about leadership.

Fellows used reflective journals to engage in open and collaborative discussion about their program experiences, and to provide an opportunity to be reflective an analytical on leadership issues and leadership development. Reflective writing was an opportunity for Fellows to think critically about what they do and why. It offered a record of events and their reactions to them and data on which to base reflective discussion.

\footnotetext{
4 Yolngu are Australian Aboriginal people from north-east Arnhem Land.

5 The organisation of Yolngu society and the management of Yolgnu knowledge occurs across two language groups and moieties referred to as yirritja and dhuwa.
} 
Engaging in open and collaborative discussion about the program informed by their journal entries provided a process that enabled Fellows to become reflective leaders.

Their journals were viewed as being a summary of daily activities connected to leadership issues and leadership development. A total of 46 reflective journals were the primary source of data. Fellows were requested to post a reflection after each major topic of the AAF program and, in the first instance to assist with the journal writing process use a journal template. The template consisted of three threads: looking back at the event (in this case a program workshop); analysing the event by thinking in depth and from different perspectives; and, thinking carefully about what the event meant for them as educational leaders. Fellows posted their journal entries on a secure Internet site, which had access restricted to the program members (workshop presenters, current Fellows and alumni). Fellows were able to comment on their own reflections but were also able to view and comment on their colleagues entries as well.

The implications for this study were that any propositions emerged from the data through inductive analysis, rather than being framed prior to the research. Inductive analysis means that the categories of analysis emerge from the data rather than being imposed prior to data collection (McMillan \& Schumacher, 1989). Once data were collected, collated and sorted, the more formal stage of data analysis took place. The formal process of data analysis was focusing the data, which involved considering data in relation to the topic of interculturalism, and drawing conclusions about the research is the typical outcome of data analysis. Throughout data analysis, and to a certain extent throughout the whole process, tentative conclusions were made and reviewed, and finally settled.

\section{Results}

Participants saw the value of the processes of reflective journals in assisting them with their ideas on intercultural leadership and helping them to understand their own cultures and the cultures of others within a leadership paradigm. One Fellow stated that "we discussed about metaphor of interculturalism which helped me understand about Fellows' cultures better" (AAF Fellows M, journal entry 4, August 2008) while another thought that it was "was a very good strategy to bring us to the thought of our own custom, tradition and culture" (AAF Fellows K, journal entry 4, August 2008). Another Fellow, 
used her journal entries to reflect on leadership, and the cultural issues that surround it. The Fellow states that:

Perhaps the concept of intercultural leadership can give us an anchor to negotiate our way through this dilemma. Intercultural leadership defined as the capacity to change our knowledge, attitudes and behaviours, as to be open and flexible to other cultures. And this capacity to change primarily hinges on the breadth and depth by which educational leader understand and appreciate their context. Eastern philosophy espouses the oneness of everything. In the Eastern symbol of yin and yang, the world consists of a delicate balance between two strong opposing forces. These two forces in effect define and shape each other. Operationally translating this, as we go through the grind of educational leadership, we could give room for "productive confusion" as we strive to work within the boundaries and limitations of our milieus. This also means training our minds to see and create points of convergence regardless of deeply embedded cultures of fragmentation. (AAF Fellow M, 2008).

What has become apparent over the four AAF programs is that the Fellows' perspectives and insights were informed and challenged by leadership theories presented, their past leadership experiences, and their current leadership positions in home countries. Therefore, Fellows have been in an influential position; as they became a link between the leadership knowledge and practice in their countries, and the West, in this case Australia. Based on AAF Fellows experiences, perspectives and insights gained through the program; there was a noticeable interest in authentic and ethical leadership theory and practices, and the desire to blend this with their own cultural traditions and practice. At the same time Fellows expressed the value of their cultures and traditions as well as recognising a growing openness to new ideas and exposure to both East and West.

\section{Discussion and conclusion}

Through the means of reflective journals in which Fellows described, discussed and analysed learning activities such as workshops they developed their ideas into a set of intercultural leadership principles:

(1) The foundations of intercultural leadership are the self-esteem and values of people in a particular group. Without strong self-esteem and good values, intercultural leaders cannot be great. 
(2) Intercultural leaders respect and value the diversity of individual cultures and encourage mutual and authentic understanding.

(3) Intercultural leaders nurture and encourage positive and authentic relationships.

These principles open further possibilities for teaching and research. CCAL's AAF programs have been a combination of the academic study of leadership with the study of roles and community expectations in developing countries, engagement with the social and cultural dimensions of education in Australian educational organisations, and the opportunity for reflective practice. The programs are significant because of their contribution to the capacity strengthening and ongoing development of influential and authentic leaders in decision-making, administration and management. The programs have supported and enhanced educational leadership in developing countries through creating and encouraging local initiatives in leadership development leading towards improved educational systems and the quality of education. For example, a mentoring program for novice teachers at a university in Vietnam designed and developed by an AAF alumni, and informed by intercultural leadership principles, though started small and not mandated, was successful in fostering teacher leadership and brought about change at a larger scope within the institution. The mentoring program later on gained its popularity within the institution and influenced larger-scale programs, from which more teachers benefited.

What the CCAL AAF programs have also done is to address the imbalance where the bulk of theory and practice in educational leadership is "drawn almost exclusively from narrowly conceived Anglo-American beliefs, philosophies and understandings" (Walker \& Dimmock, 2002, p. 199). From these programs has emerged an overlapping view of leadership that embraces alternative perspectives, is essentially intercultural, has at its heart balance, and doesn't privilege the West. 


\section{References}

Abdallah-Pretceille, M. (2006). Interculturalism as a paradigm for thinking about diversity. Intercultural Education, 17(5), 475-483.

Alterator, S. (Host). (2010, April 15). Yalmay Yunupingu, Yirrkala Community Education Centre. Chalk and talk. Podcast retrieved from http://chalkandtalk.podomatic.com/player/web/2010-0415T04_57_53-07_00

Bass, B. (1990). From transactional to transformational leadership: Learning to share the vision. Organisational Dynamics, Winter, 19-31.

Begley, P. T. (2001). In pursuit of authentic school leadership practices. Leadership in education, 4(4), 353-365.

Bouchard, G., \& Taylor, C. (2008). Building the future. A time for reconciliation. Report of the Consultation Commission on Accommodation Practices Related to Cultural Differences. Quebec: Publications du Québec.

Bulliwana, H., Frawley, J., \& Garnarradj, B. (2002). Learning through country: teachers changing things around. English in Australia, 13, 5-8.

Burns, J. M. (1978). Leadership. New York: Harper and Row.

Chan, S., Correia, A., Dang, K. A. T., Frawley, J., Inthasone, S., Kittiphanh, D., et al. (2008). Leadership is a Sacred House: South East Asian cultural metaphors on educational leadership. Leading \& Managing, 14(2), 61-73.

Coll, A. C. (2004). The intercultural challenge. Bangalore: Pipal Tree.

Dodson, P. 1998, On Leadership, Williamson Community Leadership Program Lecture, 11 May 1998, Victoria.

Duignan, P. (2006). Educational Leadership: Key Challenges and Ethical Tensions. Cambridge: Cambridge University Press.

Frawley, J., Fasoli, L., d'Arbon, T. and Ober, R (2010), The Linking Worlds Research Project: Identifying intercultural educational leadership capabilities, Leading \& Managing, 15(1), 1-15.

Kamara, M. (2009). Indigenous female educational leaders in Northern Territory remote community schools: issues in negotiating school community partnerships. Unpublished PhD thesis. Sydney: Australian Catholic University.

Leithwood, K. \& Jantzi, D. (1999). Transformational school leadership effects: a replication. School Effectiveness and School improvement, 10(4), 451-479.

Marika, R., Ngurruwutthun, D., \& White, L. (1992). Always together, yaka gäna - participatory research at Yirrkala as part of the development of a Yolngu education. Convergence, 25, 23-39.

Meer, N,, \& Modood , T. (2012): How does Interculturalism Contrast with Multiculturalism?, Journal of Intercultural Studies, 33:2, 175-196

Merton, R. K. (1957). Social theory and social structure. New York: Free Press.

Pearson, N. (2000) Our Right to Take Responsibility (Cairns, Queensland: Noel Pearson \& Associates).

Sergiovanni, T. J. (1992). Moral leadership. San Francisco: Jossey-Bass.

Sergiovanni, T. J. (2001). Leadership: What's in it for schools? . San Francisco: Jossey-Bass.

Starrat, R. J. (2004). Ethical leadership. San Francisco: Jossey-Bass.

Stogdill, R. (1974). Handbook of leadership. New York: Free Press.

Walker, A., \& Dimmock, C. (2002). Moving school leadership beyond its narrow boundaries: Developing a cross-cultural approach. In K. Leithwood \& P. Hallinger (Eds.), Second International Handbook of Educational Leadership and Administration. Dordrecht: Kluwer Academic Publishers.

Wunungmurra, W. (1989). Dhawurrpunaramirr - finding the common for a new Aboriginal curriculum. Ngoonjook: A Journal of Australian Indigenous Issues, 2, 12.

Yukl, G. A. (1989). Leadership in organisations. New York: Prentice Hall. 